\title{
Status of Higher Education in Science in T. U. Problems and Perspectives
}

\author{
INTRODUCT ION
}

\begin{abstract}
Besides the economic and social advances, a country's viability as a nation depends on the thoroughness with which the country adopts scientific and technological abilities as part of her national identity. Science and technology are essential in improving the wellbeing of both the individuals and the state. The two plilars of sclence and technology capabilities of a nation are: advanced studies in basic sclences on the one hand and the familiarisation with technology assessment and selection on the other. Thus, in all cases for every country, science and technology education has been seen as the primary route to development. Since. science teaching constitutes the most vital component of the science building program we should first promote the cause of science teaching. Further, human resources constitute the ultimate basis for the wealth of nations. Capital and natural resources are passive factors of production, human beings are the active agents who accumulate capital, exploit natural resources, build social, economic and political organisations and carry forward national development. Clearly, a country which is unable to develop the skills and knowledge of its people and to utilise them effectively. in the national economy will be unable to develop anything else.
\end{abstract}

\section{A BRIEF HISTORY}

Higher education in science in Nepal has a short history of about seventy years only. The first and foremost example of formal science teaching took place when I.Sc. course was taught in the then Tri-Chandra College established in 1918. B.Sc. level sclence teaching was started around 1948 in the same college. M.Sc. level science teaching was began in Tribhuvan University in 1966. Up to 1958 there was only one science college all over the kingdom with a little more than 100 science students in all. There were only four science colleges in 1965. In 1973 when New Education System Plan (NESP) was Implemented, we had ten science colleges in the country. With the introduction of NESP Institute of Science, among other institutes under Tribhuvan University, was created for the development and extension of science education in the country.

Higher education in science all over the country was then managed under the academic and administrative leadership of the institute. The Dr. Dhoubhadel is Professor of Chemistry at Tribhuvan University,
Kirtipur, Kathmandu Nepal. 
then educational system was converted into semester system. Later on, the then Institute of Applied Science and Technology was abolished and merged with the Institute of Science under the new name of the Institute of Science and Technology. With the growth of public interest in science education, higher education programs in science were added in a number of campuses. Unfortunately in 1985, on the recommendation of Royal Education Commission, the Institute of Science and Technology along with the then some other institutes, was abolished and the science education was converted from the technical into the general faculty status. However, in the light of the great importance of science education and the vital role of technology in the socio-economic development of the country, His Majesty the King, in his unofficial visit to the eastern development zone in 1987, had given the directive, "to place the campuses concerned with science and technology education within a Technical Inst1tute at part with the Institute of Medicine, Engineering, Agriculture and Forestry and pay adequate attention for its development. Accordingly, the Faculty of Science, Tribhuvan University has been reconstituted as the Institute of Science and Technology (IOST) with its office of Dean located Sanothimi (Bhaktapur district) on Poush 19, 2045. Thus the sum total of all the sclence and technology campuses including the Central Departments under Tribhuvan University having academic programs ranging from P.C.Sc., B.Sc., M.Sc., Ph.D. and Research has been the real shape and form of the newly constituted Science and Technology Institute entrusted with strengthening and development of all science and technology programs in higher education all over the country. At present the Institute has to look after 19 University Campuses and 6 Private Campuses with altogether more than six thousand students and 552 academic staff members.

\section{PROBLEMS AND CHALLENGES}

In spite of the remarkable growth, the problem of higher education in science are also assuming aiarming proportions. Science education in Nepal still lacks the definite national objectives, directives and policy. If we look into the state of affairs in the domain of higher education in science in general, we can identify several crucial problems which science educators and science community at large should urgently cope with. Science education in Nepal is simply academically bound and totally geared towards the academic prerequisites of the different levels of University's Science Education. The spectfic problems which plague the scientific scenarlo of our country now, I would like to mention here. All our science campuses are under great pressure to admit more students than they can cope with. So we have the morning-shifts and additional day-shifts as extra-academic burden and headache to be managed. It is in imortant factor for degrading our standard and quality of teaching in the campuses. Hence the students are unable to get due care and educational guide from their teachers. And the teachers are also helpless in spite of their zeal and enthusiasm to work.

Accomnodation in class rooms (both theory and practical) are proving to be inacequate. The equipments in the laboratories are too pathetic for scientific experimentation. Number of books in the library is scarce. Financial allocations to these campuses will not be drastically increased 
although such allocations probably pay the biggest long-term dividends to the nation. Besides these problems there is the problem of maintaining the professional ethics of the teachers and the staff as well as boosting up their morale and working efficiency. Above all, there is the burning problem of maintaining our standard of science education at par with the SAARC countries standard. We are facing at present the following challenges vis-a-vis the above mentioned problems:

1. The first and foremost challenge is the expansion of higher education in science without reducing the standard.

2. How to modernize and maintain our standard of science education at the international level or at least the level of SAARC countries?

3. How to evolve Kirtipur (campus) as centre of excellence in science enabling the Central Departments to have proper academic research environment so that they can have academic leadership in the respective disciplines all over the country?

4: How to make our $S$ and $T$ education relevant to the needs of our society and country instead of science for science sake?

5. How to impart quality science and technology education in view of the degrading situation in the educational atmosphere, although the informational content of our higher education in science in our country is not all that low?

6. How to orient our $S$ and $T$ education ecologically and to make more extensive study of our land, water and mineral resources in solving our national problems?

7. How to make our $\mathrm{S}$ and $\mathrm{T}$ education self-sustaining ?

8. How to tie-up our $S$ and $T$ education with the national program of people's basic needs fulfillment and to use $S$ and $T$ education to improve the national and cultural condition of our country-men's Iives?

9. How to improve the quality of life in a world of ever increasing technological development given the "finite" environment we live within ?

10. How to develop an appropriate environmentally oriented science education as a vital compensatory and complementary component to our existing formal higher education in science in general?

\section{PERSPECT IVES}

Be it as it may, there appears to exist a concensus at least about one thing that the science programs from our multiple campuses be separated first and convert them into unitary science campuses in order to improve the contemporary science education. This has to be achieved on 
an emergency basis. The implementation of this strategy is to be 1mmediately followed by an adequate strengthening and boosting up program regarding structure and functions as well as academic and administrative management and reform in the campuses, quality and standard of teaching learning processes in the class room, the examination procedure and calendar operations of academic sessions leading to the restoration of discipline and regular academic life in the campuses which may then be able to create the necessary self-sustaining atmospher

Also it is but imperative that the central departments in Kirtipur are to be developed as centre of excellence in basic sciences and researches. This immediately connotes that there is urgent need of special boosting up program as well as creation of an academic atmosphere in these central departments so that they will be capable to command the required academic leadership all over the country in their respective disciplines. With the growth of the developmental activities in the country it has been felt in every corner that IOST should start teaching program and research activities in the subjects of sciences in applications so essential for our country. Fields of studies such as energy Technologies, Environmental Sciences, Material Sciences, Earth Sciences, Computer and Micro-Processor applications, Remote sensing, New materials, Food Sclence and Technology, Water resource studies etc. are definitely our perspective programs to be developed in the Central Campus of IOST at Sanothimi. IOST has related 1 ts program by first starting M.Sc. Microblology program along with relevant course in Biochemistry from the coming session at Sanothimi Campus side by side with a B.Sc. program to meet the increasing demand and pressure of the students. Thus Sanothimf Campus is to be gradually converted into a centre of excellence in Research and Sciences in Application (Applied Sciences). Similarly, Dharan Campus at Hathisaar, Dharan is to be developed as centre of excellence In technology and technological researches. For this we start and add a number of useful Teehnologies, e.g. Textile, Chemical, Dairy, Industrial, Electronics etc. in addition to the strengthening and expanding the existing program of B. Tech. in food technology. Thus IOST in sum total expected to be developed something on the lines of Indian IIT or AIT Bangkok or preferably on the lines of MIT. This may later on be evolved into separate National University of $S$ and $T$ as the future need and demand of the country in the course of development. The envisaged independent functioning of IOST as a fullfledged Institute having its definite structure and organisation endowed with teaching, research, examination, planning and evaluation functions will then have the IOST central campus with Dean's office as the central coordinating office and nucleus of IOST.

\section{STRATEGIES}

The implementation of the strategies for improvement of course, requires a long constant effort for the development of appropriate workable and manageable courses and curricula. Secondly, we would have to tie up our programs in science and technology education with the national requirements of $S$ and $T$ manpower every year as per the assessment of such data from the National Planning Commission in response to the people's basic need fulfillment national commitment as well as the need of the industries, the private sectors and the society at large. 
Accordingly, we have to revise and develop the whole curricula of $S$ and $T$ education in consonance with the plan of required manpower production. Along with the suitable curriculum development the proficiency and quality of the teachers are also to be raised and looked after by periodically exposing the teachers to both national and international conferences, seminars, symposis, summer and winter schools and refresher training courses. Side by side teachers and administrative staffs' morale is to be boosted up by improving the terms and conditions of their services and also by increasing their financial and other facilities. Regarding the maintenance of student disciplines and all round development it is desirable that student counselling services are to be started for their career and proficlency and their extra-time and should be properly spent in such extra-curricular activities as seminar, sports, science fairs, orientation program, quiz contests, tours and field trips. of course all the plans and programs mentioned above will be realised only when the Institute will stand on a sound financial resources development plan in addition to the regular HMG grant. Certainly the proportionate increase of student regular examination fees. and internal mobilisation of teachers expertise in national and international project execution and- Institute/Industry interaction activities will go a long way to fulfill the required financial stringencies. Besides, the Foreign-Aid mobilisation from the different donor countries of the world, offering of courses, consultancy and expertise sale activities will also have to make a significant contribution in the direction of making the Institute self-sustaining to some extent.

\section{CONCLUSION}

From what has been said above the IOST is faced with many problems and also a very many good prospective plans and programs are to be seen in its perspectives. Every problem has its own solution. Only the lack of mind, devotion and commitment from all concerned appear as hurdles and obstacles, otherwise we have no reason why we cannot create and mafntain a fine Institute of Science and Technology at par with such ones in other countries. The only thing that is necessary for making success in our venture is the positive outlook of HMG, university administration, the teachers, the students, the general public and all those concerned with the higher education in science in the country. 